\title{
Reflections on Teaching and Learning of Mathematics through Lesson Study and Video Critique
}

\author{
Zanaton H. Iksan \\ Faculty of Education, Universiti Kebangsaan Malaysia \\ Marziah Bt Md. Rahim \\ Faculty of Education, Universiti Kebangsaan Malaysia
}

\begin{abstract}
Teachers' reflection is one important step in the implementation of Lesson Study. To enhance the professionalism of teachers, lesson study has become an important practice in the implementation of the Professional Learning Community (PLC) in Malaysia. "Video Critique" and "Lesson Study" are some of the tools in the implementation of PLC. As Lesson Study is newly introduced in 2011, teachers are still in the learning stage of implementing it. Among the problems teachers face is ways of making good reflections during classroom observation. Thus, this study aims to explore the ways in which excellent teachers reflect as well as their reflection level by looking at a video of teachers teaching at a school in Negeri Sembilan. The study was conducted using qualitative methods. The study participants were 17 excellent teachers, including two lecturers. Data was collected using reflective observations, documents of the participants, and recordings of the video critique sessions. Data was analysed using reflective dialogue session video documents analytical technique that has been transcribed. It was found that there are four stages of reflections: Descriptive, Dialogue Reflective, Descriptive Reflective and Critical Reflective. A majority of the excellent teachers reflected at the stage of Dialogue Reflective. Some of the excellent teachers made Descriptive Reflective, and only a few teachers succeeded brilliantly at Critical Reflective. Originality/value - This study implies a need for exposure to reflective practice during the process of observation so that teachers receive deep and meaningful feedback through practice in community learning.
\end{abstract}

Keywords: reflective thinking, excellent teachers, video critique, lesson study, professional learning community

\section{INTRODUCTION}

The quality of classroom teaching and learning plays an important role in producing effective and meaningful learning outcomes for students. The teacher is one of the factors that can affect academic performance and personal development of students (Bryne, 1983; Haniza, 2003; How, 2007; Rodiah, 2008). According to Cruickshank and Haefele (2010), there are several criteria that determine the quality of a teacher, and one of them is the practice of reflective thinking. Many studies have been carried out in connection with the practice of reflective thinking in the world (Hatton \& Smith, 1995; Rarieya, 2005, Hazniza, 2006; Khalid et al., 2015). This is because reflective thinking and practice are important aspects of improving teaching. In addition, teachers that practice reflective thinking can improve their efficiency in facing challenges in teaching and learning as well as being creative and innovative in solving problems in the classroom.

Therefore, reflection is an obligation for every teacher in the country. However, the question is, to what extent do teachers think reflectively in our country? The study by Nor Hazniza (2006) 
found that the majority of science teachers' thought and reflection practice was at a low level and that they were only able to reflect on trivial things. It is even more unfortunate when most teachers and lecturers do not provide full guidance about reflective writing in a personal reflection space (Azlan \& Alima, 2010). The findings of a study conducted by Yorulmaz (2006) in Poyraz and Usta (2013) on 450 teachers found that the majority of teachers did not receive any in-service training related to reflective thinking, and that they also had difficulty in making teaching plans including evaluating teaching practices. It showed that most of the teachers, especially novice teachers, must receive guidance from senior teachers as to how to reflect more deeply.

The Ministry of Education (MOE) has introduced Lesson Study under the Professional Learning Community (PLC) program among all teachers in school in stages. Lesson Study practice is still new in Malaysia compared to other countries such as Indonesia and Singapore (Zanaton et al., 2014). It is an approach intended to conduct observation of teaching in the classroom. From the aspect of teaching, lesson study conducted in school can enhance the learning experience for students in addition to improving teaching. In this program, teachers can learn collaboratively with other professional communities to improve their performance and to exchange views on the situations they face in the classroom. Studies have proven the effectiveness of the lesson study as one of the strategies that can help teachers to improve their teaching practices, including the evaluation of their teaching and learning skills (Chassels \& Melville, 2009). Lesson Study and Video Critique can improve the reflective skills of teachers. Through this process, teachers think critically about teaching and learning, exploring gaps in their knowledge, and obtaining the information needed from each other or from subject matter experts (Lewis, 2002). Hence, this study aims to explore how excellent teachers reflect on videos of teachings using a video critique.

\section{LESSON STUDY AND VIDEO CRITIQUE}

Professional Learning Communities (PLC) is an effort to improve school performance and to create a culture of learning among teachers in the school organization. It is a process in which teachers try to develop their potential through the implementation of learning and working in a team on an ongoing basis. Many researchers have defined the term learning community. Hord (1997) suggests that learning community refers to the practice of sharing knowledge with colleagues and, parents, discussing student achievement through increased activity or curriculum improvement program or student learning, while Astuto et al. (1993) believe that a learning community is the effort of teachers and school administrators to identify knowledge and share it. Overall, the researchers thought the practice of sharing and learning for teachers in professional learning communities is to improve the professionalism of teachers through the development of learning during the learning process in the classroom. There are a number of strategies and tools introduced in the implementation of the PLC. Among them are the "Lesson Study" and "Video Critique".

Lesson Study was introduced by Makoto Yoshida, an expert with extensive experience in this field (Fernandez \& Yoshida, 2004). It is one of the methods used to conduct research related to the teaching and learning process in the classroom. This method has long been used in Japan to improve student achievement. Its main objective is to train teachers to be more responsive to student learning and improve the effectiveness of teaching and learning (Saito \& Sato, 2012). Through lesson study, teachers in Japan work together to ensure that classroom teaching initiate positive change in teaching practices and student learning (Rock \& Wilson, 2005). In addition, the practice of lesson study can also help novice teachers to produce more effective 
teaching and learning. This is because in this program, novice teachers collaborate and exchange ideas with more expert and experienced teachers about their teaching and learning.

Video Critique is a method used in the realization of Professional Learning Community. It is also known as Reflective Dialogue. The use of video in teacher education was introduced in Western countries like the United States in 1960. Since then, a variety of video-based programs have been popular, from micro-teaching sessions (Borg, 1972) to the programs that involve the latest multimedia (Lampert \& Ball, 1998). At first, the recording of video in the classroom was only used by substitute teachers for evaluations (Olivero, 1965). However, in the early 1990s, video footage was first used by researchers and teachers as well in the context of the Video Club (Sherin, 1998; Tochon, 1999). Video Club works much like the Video Critique in the PLC. The process of implementation of the Video Critique in the PLC starts with the selected teachers recording their teaching, and the video recording will subsequently be shown to a meeting of teachers. Teachers in these meetings will give their reflections on their teaching. With the implementation of the Video Critique, the teachers involved can indirectly strengthen and improve the practice of reflective thinking.

\section{Reflective Thinking}

Reflection in teaching is to modify teaching to enhance teaching and learning in the classroom in the context of professional development (Mok, 2000). It is a process that is important for all teachers to improve the effectiveness of the learning process of students as they remember and analyse in detail their past teaching and learning so as to improve it in the future. With reflection, a teacher can produce more effective and meaningful learning to students. Normally, the results of this reflection will be used by teachers to improve their teaching plans (Zanaton et al., 2014). John Dewey (1933) in his book titled "How We Think?" states that individuals who practice reflective thinking will always be active in thinking about the problem, committed to finding solutions, willing to sacrifice their time to ensure that the problems encountered can be overcome, and open-minded to accept outside views with the potential to solve the problems encountered.

The process of reflective practice among teachers often involves assessing daily teaching practices in the classroom. The process is likely to involve the practitioners of reflective thinking, who are aware of and able to make a critical assessment of the situation in their own practice. Dewey in Grand and Zeichner (1984) states that there are three attitudes that should be included in teacher preparation to become a reflective thinker. First, one has to have an open mind to accept the views of various parties, pay attention to various possibilities and can identify potential errors in practice. Second, one must have a sense of responsibility to consider carefully the consequences of the actions to be taken. Finally, a reflective teacher should be willing to do their best and sincerely reflect on their classroom practices. A reflective teacher should have a sense of dedication and commitment to teaching all students in a class and not just select students.

\section{Reflection Model}

There are some reflection models that has been proposed by some researchers, such as the Reflective Teaching Model (Pollard \& Tann, 1990) and the Reflection Model (McAlpine et al., 1999), which aim to improve the ability of teachers to reflect more carefully and critically. Therefore, through this study the researchers wanted to examine the model used by excellent teachers to reflect on video recordings of teaching in schools. To analyse the evaluation level of excellent teachers, the researchers used the Reflective Writing Measurement Model proposed 
by Hatton and Smith (1995) as shown in Figure 1. There are four categories of reflection in this model: Descriptive, Descriptive Reflection, Dialog Reflection and Critical Reflection.

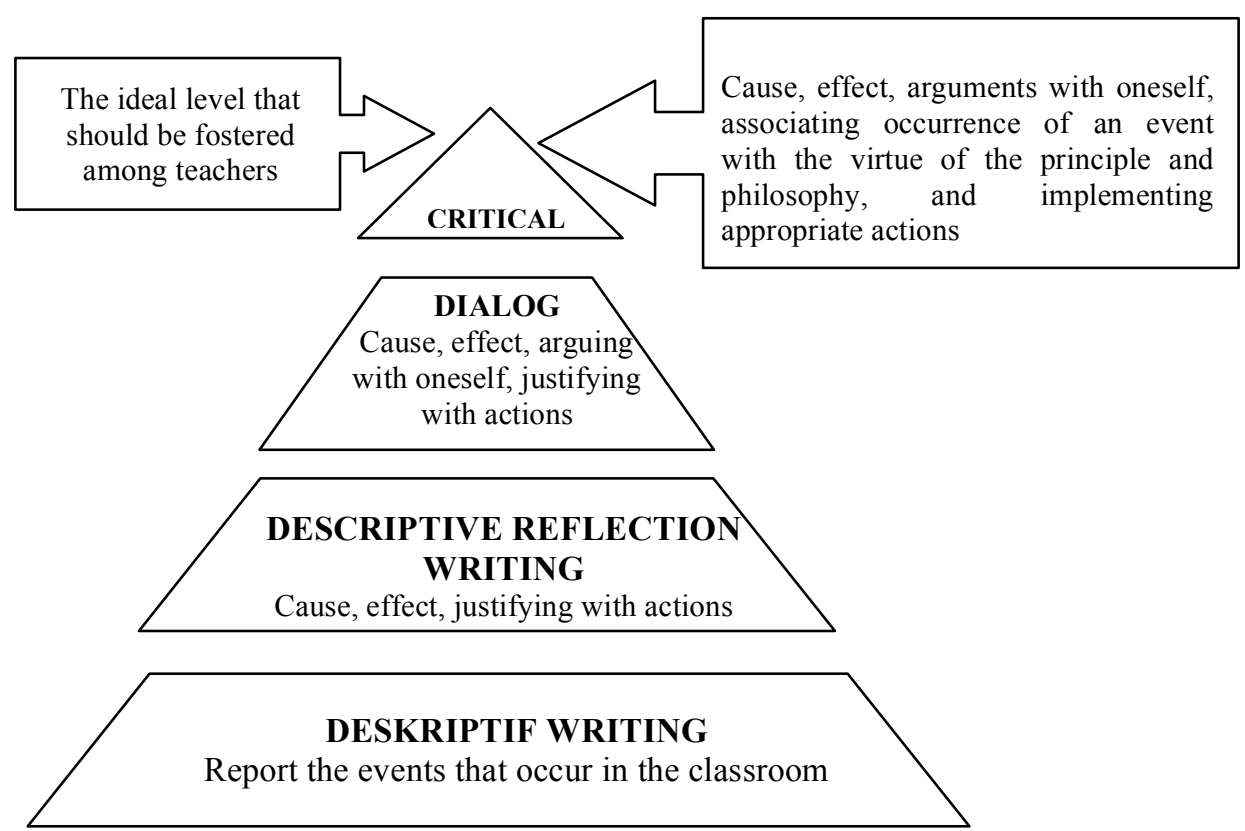

Figure 1: Levels of Reflective Writing (Source: Hatton \& Smith, 1995)

According to Hatton and Smith (1995), the lowest level in the process of reflection is 'descriptive'. At this level, teachers only report on what happened in the classroom or during teaching and learning. The second stage is the stage of 'Descriptive Reflection', where teachers can give reasons, consequences and justifications based on personal considerations of teaching and learning. The third stage is the stage of 'Reflective Dialogues', where teachers can argue with themselves or others about the causes, consequences and justifications for the actions that should be carried out in teaching and learning in the future. The highest level (and one that should be practiced by all teachers) is 'Critical', where teachers can argue with themselves or others about the causes, consequences and make a decision with regard to appropriate action in the broader historical, social, political context.

\section{METHODOLOGY}

This study aimed to explore how excellent teachers reflect on instructional videos in a prestigious secondary school in Seremban, Negeri Sembilan. A qualitative study was used to obtain data about how excellent teachers reflect on a teachers' teaching video. The participants were selected purposively and were appropriate to the focus of the study. According to Chua Yan Piaw (2014) purposive sampling refers to the sampling procedure in which a subject selected has certain features that coincide with the focus of the study. Therefore, the criteria for selecting participants in this study was that they were excellent teachers or employees of the District Education Office, Seremban, Negeri Sembilan, and were involved in the implementation of lesson study. Participants involved in the study consisted of 17 excellent teachers from a variety of different specialties.

The instrument is observation and reflection of participants' video recording and the transcript of the recordings. The researchers chose to use video recordings to collect data because it is easy to use and facilitates researchers obtaining information for the focus of the study. Another advantage of using video as an instrument of data collection is that it is easily accessible, it can be shared and researchers can repeat the data analysis process (Jewitt, 2012). The structure of 
the video critique is divided into three activities, namely briefing (pre-reflective dialogue), video watching sessions, and reflection dialogue. Briefing was conducted before the reflection dialogue initiated by the participants. The moderator explained the study to the participants. Each participant was required to specify the focus of the observation to be discussed during reflection. However, other elements may be judged according to the needs of the participants. After the explanations were given, an instructional video session of a math teacher entitled "Interception" and "Union" was presented to all participants of the study. After watching the video, all participants gave their reflections on the teaching openly based on the focus that they had chosen. The researcher was an observer in this study. The process of reflective discussion of the participants was recorded. The data collected in the form of video recordings was then transcribed by the researchers as a whole.

\section{DATA ANALYSIS}

Miles and Hubermann (1994) state that the process of analysing qualitative data requires a detailed study because of its data projections, and the transcript can have many different meanings. Therefore, the analysis of observational data of the excellent teachers' reflections involves five stages. The first stage is data collection, which was when the participants reflected on the videos and recorded on video, while the second stage was the process in which researchers listened, took notes and copied the transcripts from the video footage. The third stage of the data analysis process of this study was the reading and coding of the transcript according to the theme and sub-themes. After the transcript was coded, it was discussed with the evaluator. The fourth stage was the peer-review process based on the theme and subthemes that had been determined. The final stage was the process of making the formulation and justification of the data that had been analysed and the writing of the reports for the findings of this study.

\section{RESULTS AND DISCUSSION}

The results of the analysis of observational data and transcripts of video recordings are divided into two main sections: (1) excellent teachers' reflection model to Video Critique and (2) the level of reflection of excellent teachers. The first part of the study is the analysis of the participants' reflection on the teacher's instructional videos and drafting reflection model used by excellent teachers. In the second part, the researchers looked at the reflection level according to the model of excellent teachers by Hatton and Smith (1995).

\section{Excellent Teachers' Reflection Model towards Video Critique}

The results of this study found that there are three phases in the excellent teachers' reflection model towards the Video Critique. The first phase is focused reflection followed by a phase of analysis, which states the strengths and weaknesses of teaching and learning, and the final phase is the conclusion. Figure 2 shows the excellent teachers' reflection model towards Video Critique in this study. 


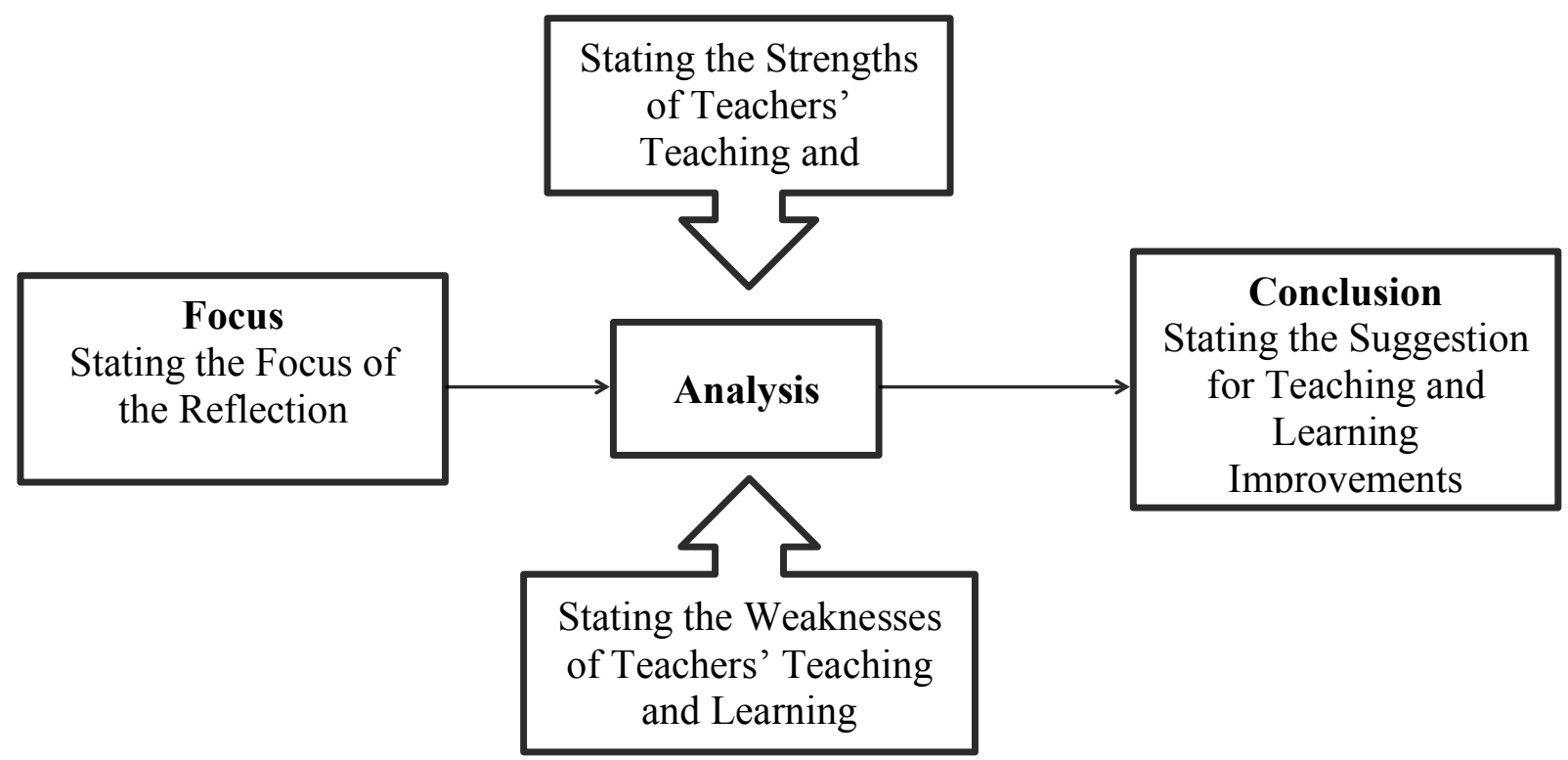

Figure 2: Excellent Teachers' Reflection Model towards Video Critique

The first phase in this reflection model is the focus phase, in which the participants are required to declare their reflective focus on the instructional videos that have been viewed. The participants were required to set the focus of observation to be discussed during reflection. However, other elements may also be assessed according to the needs of the study participants. The focus is to facilitate the teachers being critiqued in taking notes and getting an overview of the reflections given by the excellent teachers on their teaching videos. Overall, the researchers found that the majority of participants' reflections focused on students' participation in the classroom. Table 1 shows that the majority of teachers focused on students' participation in their reflections more than on teaching methods and materials.

Table 1: Reflection focus of excellent teachers

\begin{tabular}{ll}
\hline \multicolumn{1}{c}{ Reflection Focus } & Examples of Reflections \\
\hline Students" & "My focus is on the students' participation in the classroom." \\
"I am making a reflection on the student's participation." & "My reflection focus is related to the students' participation in the \\
& $\begin{array}{l}\text { classroom." } \\
\text { "I am giving a focus on the students' participation in the group } \\
\text { activities handled by the teacher." }\end{array}$
\end{tabular}

Teaching methods "I am looking for the teaching methods."

"I am focusing on the ways teachers handle the activities."

"I am focusing on the teachers' teaching"

Teaching materials "I am looking on the overall pedagogy and focusing on the use of ICT in the teaching and learning."

The second phase in the reflection model is the analysis phase, where the excellent teachers give their reflections on teaching and learning as a whole, including stating the strengths and weaknesses of the teaching and learning. The results of data analysis found that there were a number of teaching and learning strengths identified by the participants towards the teaching video. Among them, a majority of participants said that teaching is planned systematically and 
effectively. Planning is very important in determining the effectiveness of teaching and learning. According to Wong (2009) in Cicek and Tok (2014), effective teachers should have positive expectations for student success, should make lesson plans to reflect these expectations, and should know how to design the instruction for students' mastery.

Some participants said the teachers' action to plan and produce teaching and learning that involves students in group activities is a very good strategy and an effective way to improve students' understanding. Through group activities, students can share ideas and knowledge more meaningfully. A study of cooperative learning has shown a positive relationship between student achievement and attitudes about learning (Slavin, 1989). In addition, the use of ICT in teaching and learning also received praise and positive comments from the participants. Half of the participants were of the opinion that the use of ICT in teaching and learning such as PowerPoint attracts the students' interest and attention and enhances their understanding of the concepts learned. This is because studies done locally and abroad show that the use of ICT in teaching can increase both students' interest and achievement in academics (Jamalludin \& Zaidatun, 2003; Macaulay, 2002; Al-Mikhlafi, 2006). This statement is also supported by the findings of Abu Ziden et al. (2011), which found that the use of ICT in teaching and learning could improve student achievement in science subjects in primary schools.

Several participants reflected on teachers' rewarding their students, and they thought that the reward system was a good thing and can increase students' motivation to learn. Rewarding can increase motivation and competition among students. The idea was also supported by a study that stated that motivation could increase when there are strong external factors such as incentives and rewards (Bowman, 2007; Hoffman et al., 2009). Table 2 shows examples of participants' reflection on the advantages of teaching and learning that has been carried out by the teacher.

Table 2: Examples of Reflection towards the Strengths of Teaching and Learning

\begin{tabular}{cc}
\hline Examples of Reflection & $\begin{array}{c}\text { Strengths of Teaching and } \\
\text { Learning }\end{array}$ \\
\hline
\end{tabular}

"The teaching and learning are systematic because teachers have a particular direction in the conduct of all activities. Teachers have a clear objective in making a lot of activity in the teaching and learning as well as the planned objectives can be achieved."(T17)

"Teachers have produced excellent PowerPoint slides that are easy to understand and can attract students to teaching and learning." (T5)

"Students work in groups. They seem to have a meaningful discussion in which they try to solve all the problems given together. This is very good and can improve their understanding "(T7)

"Teachers give rewards to the students. She also praises the students and they seem to be interested in the teaching and learning."'(T10)
Systematic and effective teaching and learning.

Usage of ICT in teaching and learning

Cooperative learning

Rewarding students

Noted: T - Teacher 
Analysis of the data revealed that the majority of participants were able to give suggestions for improvement of future teaching and learning. It shows that some of the excellent teachers can justify taking appropriate action in order to solve problems in teaching and learning. Table 3 shows an example of reflection containing recommendations for the improvement of teaching and learning.

Table 3: Examples of reflection and recommendations for the improvement of teaching and learning

\begin{tabular}{|c|c|}
\hline Teacher & Examples of Teaching and Learning Improvements Recommendation \\
\hline T1 & $\begin{array}{l}\text { "I think it is better if the teacher can provide a space for students to try out for } \\
\text { themselves first because I think the students could learn more quickly when } \\
\text { studying with others." }\end{array}$ \\
\hline T7 & $\begin{array}{l}\text { "I think it is better if the teacher gave a comment or opinion on the responses } \\
\text { of students before moving on to the next step." }\end{array}$ \\
\hline T11 & $\begin{array}{l}\text { "I think it is better if the teacher can show students examples of correct work } \\
\text { and explain why the results were correct. It is important for students to know } \\
\text { whether their answers are right or wrong." }\end{array}$ \\
\hline
\end{tabular}

\section{Excellent Teachers' Reflection Levels}

The findings of this qualitative study's data analysis found that the reflection levels of excellent teachers can be categorized into four levels according to the reflection level model by Hatton and Smith (1995), which are Descriptive, Descriptive Reflection, Dialogue and Critical Reflection. The levels of excellent teachers' reflection can be seen in Table 4.

Table 4: Excellent teachers' reflection level

\begin{tabular}{|c|c|c|c|c|}
\hline Teacher Code & Descriptive & $\begin{array}{l}\text { Descriptive } \\
\text { Reflection }\end{array}$ & $\begin{array}{l}\text { Dialogue } \\
\text { Reflection }\end{array}$ & $\begin{array}{c}\text { Critical } \\
\text { Reflection }\end{array}$ \\
\hline G1 & - & - & $\sqrt{ }$ & - \\
\hline $\mathrm{G} 2$ & - & - & $\sqrt{ }$ & - \\
\hline G3 & - & $\sqrt{ }$ & - & - \\
\hline G4 & - & $\sqrt{ }$ & - & - \\
\hline G5 & $\sqrt{ }$ & - & - & - \\
\hline G6 & - & $\sqrt{ }$ & - & - \\
\hline G7 & - & - & $\sqrt{ }$ & - \\
\hline G8 & - & - & $\sqrt{ }$ & - \\
\hline G9 & - & $\sqrt{ }$ & - & - \\
\hline G10 & - & $\sqrt{ }$ & - & - \\
\hline G11 & - & - & $\sqrt{ }$ & - \\
\hline G12 & - & - & $\sqrt{ }$ & - \\
\hline G13 & - & $\sqrt{ }$ & - & - \\
\hline G14 & - & - & $\sqrt{ }$ & - \\
\hline G15 & - & - & $\sqrt{ }$ & - \\
\hline G16 & - & - & $\sqrt{ }$ & - \\
\hline G17 & - & - & - & $\sqrt{ }$ \\
\hline
\end{tabular}

From the table above, it can be seen that the majority of the participants can reflect on the third level, which is Reflection Dialogue. At this stage, teachers should be able to reflect on giving reasons, consequences, and justifications of the actions carried out for teaching and learning in the future. For example: 
"I can see students getting involved in teaching and learning and teachers have a good strategy in helping students to recall the past lessons. This is because students seem to pay attention and are able to respond to teacher questions. Students work in teams to create activities. They seem to have a meaningful discussion in which they try to solve all the problems given together. I think it is better if the teacher can give students the opportunity to try out for themselves first because I think the students could learn more quickly when studying with others. (T8)

Analysis of the data also revealed that some participants reflect on the second level, namely the level of 'Descriptive Reflection', where teachers give reasons, consequences, and justifications based on personal considerations on teaching and learning. For example:

\begin{abstract}
"I want to give a response to the quality of teaching and learning materials. At first, I thought the idea of using different colours and shapes in identifying different sets is very nice, especially for the weak students. This is because it is easier to understand. Students also prefer this method. But there is an error in PowerPoint slides, where in the questions teachers say "shade the area" but in the slide the teacher says "colour the area". This can lead to a 'misconception' for students."(T4)
\end{abstract}

However, there is only one participant that can reflect on the first stage, which is the descriptive level. In addition, a few of the participants managed to reflect on the highest level, which is Critical Reflective. Based on the above findings, the researchers conclude that the majority of excellent teachers can reflect well, but still have not reached the critical-thinking level. It is shown that despite these teachers being categorized as excellent, they do not yet have the ability to reflect critically. Arguably, the excellent teachers and master teachers have not been able to critically reflection, let alone novice teachers who have had little to no experience of teaching in schools. This finding can be said to support the findings of the study carried out by Hatton and Smith (1995), who found that many of the trainees are able to reflect at the third and fourth stages. This is similar to the findings of the study by Nor Hazniza (2006), which states that a majority of science teachers still do not reflect well.

In addition, the findings also show that all teachers should be exposed to how to critically reflect since training. This is because there are studies that indicate that trainee teachers are not given training in reflective thinking in teacher training institutes (Yorulmaz, 2006; Azlan \& Alima, 2010). In addition, Portner (1998) also noted that teachers experienced difficulty in preparing lesson plans and often repeated the same mistakes, despite being given advice and warnings by the evaluators. Therefore, efforts and initiatives should be undertaken to improve the quality of teaching, and the practice of reflective thinking should begin with the training of teachers. In Japan, all the trainees were introduced to Lesson Study at the training level (Zanaton et al., 2013).

This study also shows that the practice of "Video Critique" can help teachers to have new ideas and improve their teaching practices in the classroom. According to Clarke and Hollingsworth (2000), video recordings can accentuate the impression of the classroom that teachers may not have noticed in the course of teaching and learning. Sometimes, when teachers plan and carry out learning and teaching sessions, they are likely to lose sight of the strengths and weaknesses that should be corrected. Chad (2012) stated that this method can help teachers engage in reflective thinking constantly and learn through experience and can prevent them from repeating the same mistakes throughout their career. However, to be involved in the Video 
Critique, teachers must be prepared mentally such as having an open mind to listen to the views of others and the determination to improve their teaching practices.

\section{CONCLUSION}

Reflection is one of the most important practices in teaching. This is because in reflecting on teaching, the teacher is able to evaluate their effectiveness in the classroom. In addition, teachers can also increase the practicing of the profession and can produce quality students. The practice of reflection in a cooperative and collaborative way as conducted in Lesson Study and Video Critique can improve their practices in the classroom. However, in Malaysia this is still in the learning stages and has not been cultivated in the education system. Therefore, this practice should be fully practiced at all levels of educational institutions in order to produce more professional teachers and to improve student outcomes.

\section{ACKNOWLEDGEMENT}

Thank you for Fiscal Year 2013 Grant for Japan Related Research Projects - The Sumitomo Foundation (Reg. No: 138429) and UKM grant (DPK-2014-007)

\section{References}

Al-Mikhlafi, A.G. (2006). Effectiveness of interactive multimedia environment on language acquisition skills of 6th grade students in the United Arab Emirates. International Journal Media. 33(4):427-441.

Astuto,T.A., Clark, D.L., Read,A-M., McGree, K. \& Fernandez, L.deK.P. (1993). Challenges to Dominant Assumptions Controlling Educational Reform. Andover, MA: Regional Laboratory for the Educational Improvement of the Northeast and Islands. Dicapai dari http://www.sedl.org/pubs/change34/plc-cha34.pdf pada 15 Oktober 2015

Azidah et al. (2011). The Effects of ICT Use in Teaching and Learning on Students' Achievement in Science Subject in a Primary School in Malaysia. Malaysia Journal of Distance Education. 13(2):19-32.

Borg, W. R. (1972). The Minicourse as a Vehicle For Changing Teacher Behavior: A Three Year Follow-up. Journal of Educational Psychology, 63(6), 572-579

Bowman, R. (2007). How can students be motivated: A Misplaced question? The Clearing House,81(2), 8 1-86.

Carey Jewit. (2002). An Introduction in Using Video for Research. National Centre for Research Methods Working Paper. Institute of Education. London

Byrne, C.J. (1983). Teacher Knowledge and Teacher Effectiveness: A Literature Review, Theoretical Analysis and Discussion of Research Strategy. Paper Presented at the Meeting of the Northwestern Educational Research Association, Ellenville, NY.

Chad West. (2013). Developing Reflective Practitioners: Using Video-Cases in Music Teacher Education. Journal of Music Teacher Education, Vol 22(2), 11-19 Dicapai dari doi: 10.1177/1057083712437041

Chassels, C. \& Melville, W. (2009). Collaborative, Reflective, and Interative Japanese Lesson Study in an Initial Teacher Education Programme : Benefits and Challenges. Canadian Journal Education, 32(4), 734-763

Chua, Y.P. (2014). Kaedah dan Statistik Penyelidikan Buku 1: Kaedah Penyelidikan. McGraw-Hill Education (Malaysia) Sdn.Bhd. Selangor

Cicek,V. \& Tok, H. (2014). Effective Use of Lesson Plans to Enhance Education in U.S. and Turkish Kindergarden Thru 12th Grade Public School System: A Comparative Study. International Journal of Teaching and Education.Vol II(2), 10-20

Clarke, D., \& Hollingsworth, H. (2000). Seeing is Understanding. Journal of Staff Development, 21(4), 40-43.

Cruickhshank, D.R., Haefele, D. (2001). Good Teachers, plural. Educational Leadership, 58(5), 26-30.

Dewey, J. (1933). How We Think. A Restatement Of The Relation Of Reflective Thinking To The educative Process. Boston. D.C. Heath and Company

Fariza Khalid et al. (2015). Membangun Kapasiti Pemikiran Reflektif Pelajar Melalui Kursus Komputer dalam Pendidikan. Seminar Kebangsaan Majlis Dekan-Dekan Pendidikan Universiti Awam 2015. Universiti Tun Hussein Onn. Johor 
Fernandez, M.L. (2005). Learning Through Microteaching Lesson Study in Teacher Preparation. Action in Teacher Education, 26(4), 37-47. http://dx.doi.org/10.1016/j.tate.2009.09.012

Fernandez, C. \& Yoshida, M. (2004). Lesson Study: A Japanese Approach to Improving Mathematics Teaching and Learning. Mahwah, NJ: Lawrence Erlbaum.

Grand, C.A \& Zeichner, K.M. 1984. On Becoming A Reflective Teacher. Socialization and Progress.Dicapai http://www.wou.edu/ girodm/foundations/Grant_and_Zeichner.pdf pada 19 Oktober 2015

Haniza Abdul Khalid. (2003). Attitude and Motivation Toward English as a Medium of Instruction. Kertas Projek Program Sarjana (Tidak Diterbitkan). Bangi: Universiti Kebangsaan Malaysia

Hatton, N. dan Smith, D. (1995). Reflection in teacher education: Towards definition and implementation. Teacher and Teacher Education. 11(1), 33-49

Hoffman et al. (2009). Elementary Teachers' Use and Perception of Rewards in the Classroom. Teaching and Teacher Education,25, 843-849.

Hord, S. M. (1997). Professional Learning Communities: What Are They and Why Are They Important? Issues About Change, Vol 6 (1). http://www.sedl.org/change/issues/issues61/Issues_Vol6_No1_1997.pdf pada 5 Oktober 2015

How, Lee Chan. (2007). Faktor-faktor yang Mempengaruhi Gejala Ponteng di kalangan Pelajar Sekolah Menengah. Kertas Tesis Sarjana (Tidak Diterbitkan). Skudai: Universiti Teknologi Malaysia

Jamalluddin Harun \& Zaidatun Tasir. (2003). Multimedia dalam Pendidikan. Bentong: PTS Publication.

Lampert, M., \& Ball, D. L. (1998). Teaching, Multimedia, and Mathematics. New York: Teachers College Press.

Lewis, C. (2002). Lesson study: A Handbook of Teacher-led Instructional Change. Philadelphia, PA: Research for Better Schools, Inc.

Loughran, J. (2002). Effective Reflective Practice. In Search of Meaning About Teaching. Journal of Teacher Education, 53(1): 33-43.

Macaulay, M. (2002). Embedding Computer Based Learning With Learning Aids: A Preliminary Study. International Journal Of Instructional Media. 29(3):305-315.

McAlpine et al. (1999). Building a metacognitive model of reflection. Higher Education. 37, 105-131.

Miles, M. B., \& Huberman, A. M. (1994). An Expanded Sourcebook: Qualitative data Analysis. Thousand Oaks, CA: Sage.

Mok Soon Sang. (2002). Pedagogi 2: Pelaksanaan Pengajaran 2. Selangor: Kumpulan Budiman.

Noor Azlan dan Sharifah Aklima Nadia. (2010). Persepsi Guru Pelatih Matematik UTM Terhadap Penulisan Reflektif Semasa Latihan Mengajar. Fakulti Pendidikan. Universiti Teknologi Malaysia

Nor Hazniza Ibrahim et al. (2006). Kepentingan Pemikiran dan Amalan Refleksi dalam Pengajaran Sains di Kawasan Luar Bandar. Fakulti Pendidikan. Universiti Teknologi Malaysia.

Olivero, J. L. (1965). The Use of Video Recordings in Teacher Education. ERIC Document Reproduction Service No. ED011 074, Stanford University.

Pollard, A. \& Tann, S. (1990). Reflective Teaching in The Primary School: A Handbook For the Classroom. London: Cassell.

Portner, H. (1998). Mentoring New Teachers. Thousand Oaks. CA: Corwin Press

Poyraz, C \& Usta, S. (2013). Investigation of Preservice Teachers' Reflective Thinking Tendecies in term of Various Variences. International Journal on New Trends in Education and Their Implications. Vol(4) Issue: 2 Article: 12 ISSN 1309-6249

Rarieya F.A. (2005). Reflective Dialogue: What's in it For Teachers? A Pakistan Case. Journal Of In-Service Education, 31 (2), 313-335

Rock,T.C. \& Wilson, C. (2005). Improving Teaching Through Lesson Study. Teacher Education Quarterly. Retrieved from http://files.eric.ed.gov/fulltext/EJ795305.pdf on 22 October 2015

Rodiah Ahmad. (2008). Pengajaran Guru, Persekitaran Pembelajaran dan Sikap Murid dalam Pembelajaran KOMSAS. Tesis Program Sarjana Pendidikan (Tidak diterbitkan). Pulau Pinang, Universiti Sains Malaysia. 
Saito, E. \& Sato, M. (2012). Lesson Study as an Instrument for School Reform: A Case of Japanese Practises. Management in Education, 26(4), 181-186. http://dx.doi.org/10.1177/0892020612445101

Sharifah Md.Nor. (2000). Keberkesanan Sekolah: Satu Perspektif Sosiologi. Serdang. Universiti Putra Malaysia

Sherin, M. G. (1998). Developing Teachers' Ability to Identify Student Conceptions During Instruction in: S. B. Berenson, K. R. Dawkins, M. Blanton, W. N. Coulombe, J. Kolb, K.Norwood, \& L. Stiff (Eds.), Proceedings of the Twentieth Annual Meeting of the North American Chapter of the International Group for the Psychology of Mathematics Education (pp. 761-767). Columbus, OH: ERIC Clearinghouse for Science, Mathematics, and Environmental Education.

Silins, H. \& Mulford, B. (2002). Schools as Learning Organizations: The Case For System, Teacher and Student Learning. The Journal of Educational Administration. 40(5), 425-446.

Slavin, R. E. (1989). Research on cooperative learning: An international perspective. Scandinavian Journal of Educational Research, 33(4), 231-243. DOI:10.1080/003138389033040

Tochon, F. V. (1999). Video Study Groups for Education, Professional Development, and Change. Madison, WI: Atwood Publishing.

Walkington, J. (2005). Becoming A Teacher: Encouraging Development of Teacher Identity Through Reflective Parctice. Asia-Pasific Journal of Teacher Education, 33(1), 53-64. Dicapai daripada http://dx.doi.org/10.1080/1359866052000341124 pada 10 Oktober 2015

Wong, H. K. Wong, R. T. (2009). The First Days of School: How to Be an Effective Teacher. Harry K. Wong Publications, 12, 81, 87

Yorulmaz , M. (2006). Reflective Thinking of Views on the Working Class at Primary Teachers and Evaluating Their Application ( Diyarbakir Example) . Unpublished Master's Thesis. Institute of Social Sciences . Firat University. Elazig.

Zanaton H. Iksan et al. (2013). Assessment During the Intergration of Lesson Study in Microteaching among Preservice Teachers. Asian Social Science. Vol 9(16), 112-119. http://dx.doi.org/10.5539/ass.v9n16p112

Zanaton H. Iksan et al. (2014). Lesson Study (Jogyoukenyu): Kajian Perbandingan Jepun dan Malaysia. Fakulti Pendidikan. Universiti Kebangsaan Malaysia. Dicapai daripada https://www.academia.edu/9833853/Lesson_Study_Jogyoukenyu_Kajian_Perbandingan_Jepun_dan_Malaysia pada 10 Oktober 2015 